\title{
sciendo
}

\section{Organizational diversity and competency-based performance: The mediating role of employee commitment and job satisfaction}

\author{
Victor Kwarteng OWUSU \\ Faculty of Management and Economics, Tomas Bata University in Zlin, Czech Republic \\ owusu@utb.cz \\ Ales GREGAR \\ Faculty of Management and Economics, Tomas Bata University in Zlin, Czech Republic \\ Alex NTSIFUL \\ Faculty of Management and Economics, Tomas Bata University in Zlin, Czech Republic
}

\begin{abstract}
Diversity amongst the workforce within central Europe has experienced some form of evolution. This occurrence will incessantly manifest even further in the not-too-distant future. As a result, citizen-dominated societies are gradually tilting towards an increasingly diverse and minority population, broadly of African and Asian descent. Again, demographers suggest the influx of women, minorities, people of different ethnic backgrounds, aging workers, and people with alternative lifestyles within the European employment space, just as the various organizations and schools are filled with these groups. Studies on organizational diversity abound, however, findings from past research on diversity and performance relationships have been equivocal. Thus, the main objective of this study is to assess the mediating role of commitment and job satisfaction in the relationship between diversity and performance. Results from 237 samples drawn from the Czech Republic, Europe and analyzed through partial least square structural equation modelling (PLS-SEM) suggest that diversity does not have a significant relationship with competency-based performance. However, both commitment and job satisfaction play notable roles in the relationship between diversity and competency-based performance. Given these results, we discuss the theoretical and managerial implications.
\end{abstract}

Keywords: diversity, competence-based, performance, commitment, satisfaction.

Please cite the article as follows: Owusu, V.K., Gregar, A., Ntsiful, A. (2021). "Organizational diversity and competency-based performance: The mediating role of employee commitment and job satisfaction", Management \& Marketing. Challenges for the Knowledge Society, Vol. 16, No. 4, pp. 352369, DOI: $10.2478 /$ mmcks-2021-0021.

\section{Introduction}

There has been a gradual change in the diversity of the workforce within central Europe (King, 2019). This occurrence will continually manifest even further in the not-too-distant future. As a result, citizen-dominated societies are gradually tilting towards an increasingly diverse and minority population, broadly of African and Asian descent. Again, demographers 
suggest the influx of women, minorities, people of different ethnic backgrounds, aging workers, and people with alternative lifestyles within the European employment space (Alba \& Duyvendak, 2019; Hakim, 2019; Sullivan, 2018). Academic institutions are not an exception to this emerging phenomenon. According to Kools and Stoll (2016), organizations will progressively begin to experience such a trend as most schools and organizations tend to annex talents from diverse backgrounds. Thus, prospective students and employees from diverse backgrounds with different skills, knowledge, and capacity will collectively work to sustain their organization's competitive advantage. Moreover, a shift in the demographic workforce is effectively and efficiently managed to achieve a competitive and economic outcome for organizations and schools (Ness \& Lin, 2019).

Indeed, managerial techniques, values, and strategies adopted are mostly copied from the private sector into the public management systems of school administrations and other institutions (Alford \& Greve, 2017). Nevertheless, research has produced two schools of thought. One school of thought believes that some dose of acceptance from managerial practice in the right proportion and context may be helpful to institutions in affecting the quality of job performance (Shalley \& Gilson, 2017). The other point of view, in contrast, proposes that managerial practices adopted from the private sector (Managerial Adoption) defeats the original intention of efficient and effective quality improvement in institutions (Siyambalapitiya et al., 2018). Nevertheless, these adoptions affect the efficiency and effectiveness of the various employees within an organization when its application does not consider the organization's peculiar needs (Forés \& Camisón, 2016).

Even though diversity is extremely vital due to attracting talents from different backgrounds, few studies have emphasized the mediating consequence of employee commitment and job satisfaction. Thus, the main objective of this research is to assess the mediating role employee commitment and job satisfaction play in the diversity and performance relationship.

Our study's contributions are as follows: First, we assess the relationship between diversity and performance. The study also seeks to widen the scope of diversity management and performance literature. While we have many studies on diversity, few of them have focused on educational institutions. Thus, our study enhances existing literature on diversity and performance nexus from an educational institution perspective. Secondly, we also evaluate the mediating role that employee commitment and job satisfaction might play in diversity and performance. Indeed, there is a dearth of research on the mediating role these variables play in organizational diversity studies. Thus, the paper seeks to provide empirical evidence which identifies some prime concepts which give further insights into diversity and performance within organizations.

The paper subsequently continues with a review of the theoretical foundation on employee diversity, employee commitment, employee satisfaction, and competency-based performance of employees. Hypotheses were formulated out of the research model and subsequently tested. A methodological procedure that details the data collection process is also elaborated. Results, general discussion, research implications, and finally, the conclusions, limitations, and future research directions are expounded. 


\section{Literature review and hypothesis development Employee diversity}

Consistent with extant literature, employee diversity includes personal characteristics such as gender, age, race, income and educational level, and generational differences (Pinar et al., 2011; Zopiatis et al.,2014). Diversity can be categorized into two, namely primary diversity and secondary diversity. The primary diversity consideration (age, race, gender, and experience) is paramount to this research rather than secondary diversity considerations (functional, informational, or job attributes). Primary diversity focuses on visible characteristics, while secondary diversity bothers on invisible characteristics (Hakim, 2019). Therefore, the primary diversity consideration is thoroughly examined in this research to explain diversity further. To better understand the diversity concept, we take inspiration from the theory of relational demography. Relational demography theory assumes that demographic characteristics such as educational level, age, gender, socioeconomic status, and race are essential in influencing work outcomes (Archer, L., \& Francis, B. 2006). To this end, Goldberg et al. (2010) further explains that these characteristics promote work outcomes due to homophile effect-the idea that the bond between similar people occurs at a higher rate than among people who are dissimilar, and such human inclination make people sense some interpersonal attraction. Avery et al. (2008) note that employees perceive working environment as supportive when they share demographic similarities. This may motivate employees to work. As such, every organization, whether a non-profit or a for-profit organization, will require diversity in order to be more creative, innovative, and adaptable to global changes (Přívara \& Kiner, 2020; Pudjiarti, 2018). Therefore, managers must recognize the benefits their organizations are likely to gain when they increase diversity in their workplace (Guest, 2017). Even though diversity improves organizational creativity, the challenge that comes with managing a diverse workgroup requires organizational heads to acquire the necessary skills that may enable them to adequately manage a diversified environment (Hajro et al., 2017). However, for organizations to value multi-diversity, managers and supervisors must be ready to re-orient themselves on how to lead a diverse team and equally train subordinates to work in a diverse team and support each other (Zahra et al., 2020). According to Archer \& Francis (2019) diversity generally is acknowledging, understanding, accepting, valuing, and celebrating differences among people concerning age, race, gender, and experience. Given the increasing diversity in central Europe, it is incumbent on firms to look for ways to become practically inclusive due to the potential benefits associated with workforce diversity(Cunningham, 2019). Moreover, employers and employees benefit from diversity through interdependency and respect for individual differences (Guillaume et al., 2017). Finally, diversity is critical for organizational success in an era where flexibility and creativity are keys to competitiveness (Ferreira et al., 2020).

\section{Commitment and satisfaction in an organization}

Organizational commitment can be described as an available or willing action that is not part of the role of the employee or formally rewarded by the organization (Vuong et al., 2020). Some researchers believe that organizational effectiveness is affected by organizational commitment by enhancing the social and psychological contract between the employee and employer (Ahmad et al., 2019; Vuong et al., 2020). Since organizations cannot predict or anticipate the behavior of employees, it becomes essential to have employees who have strong attachment towards an organization since that may influence their attitude and 
behavior at the workplace (Habib et al., 2019; Themba et al., 2019). This perceived connection between commitment and employee behavior has attracted the interest of scholars in studying the antecedent and predictors of employee commitment (Ahmad, 2018). For instance, there is the proposition that employee positive job attitudes are determined by commitment (Solinger et al., 2016; Villanueva-Flores et al., 2017). Again, some authors believe that an attitudinal indicator of how an employee sees himself or herself regarding the social member exchanges between the employer and employee determines the employee's level of commitment (De Roeck \& Maon, 2018; Lavieri \& Bhat, 2019; Stojanovic et al., 2020). In addition, an employee's psychological attachment to an organization due to the relative aim and value congruence, behavioral investments, and willingness to stay in an organization is attributed to commitment (De Roeck \& Maon, 2018).

Employee satisfaction is a broad term used by the human resource literature to describe how satisfied or content employees are with elements such as their jobs, experience, and the organization they work for (Bratton \& Gold, 2017). One of the primary goals of every organization is to achieve its objectives through its employee's skills and effort. However, what has to be noted is that employees exert more effort into the achievement of organizational objectives when they become satisfied with their job (Badubi, 2017). The logic is that employees reciprocate their satisfaction by taking good care of their organization's customers, which in effect result in satisfied customers and more productivity (Kloutsiniotis \& Mihail, 2018). Generally, employee satisfaction emanates from many job satisfaction elements such as good pay, good training programs, and job security (Addis et al., 2018). Hence, organizations that provide these elements to their employees are more likely to have satisfied employees than organizations that do not make these elements available to their employees.

\section{Competency-based performance}

A key indicator for the determination of employee productivity is job performance. Moreover, in order that organizations determine whether an individual employee's output meets the organizational expectations, they have to use organizational performance appraisal. Nevertheless, employees must be equipped with the skills and expertise required as a precondition for utmost performance. So, human capital is an important aspect to attain these goals (Kadiresan et al., 2015). As Habib et al. (2019) explained that human capital development has been empirically determined by researchers to be an important factor in employee organizational performance. Indeed, organizational variable remains one of the critical variables which most studies in the area of management explore (Al-Abdullat \& Dababneh, 2018; Bileviciute et al., 2019). Besides, market competition for patronage, ideas, and investment are pre-requisite for organizational performance (Lee, 2019). Organizational performance, as a consequence, has a central role in the realization of organizational goals; therefore, various departments such as operations, marketing, human resources all eventually seek to enhance organizational performance (Roberson, 2019).

\section{Diversity and competency-based performance}

Diversity can be either detrimental or beneficial for employee performance. Various works on workplace diversity have confirmed this view. For instance, King et al. (2009) posit that employee diversity significantly influences organizational creativity and responsiveness (Kittay, 2019). Likewise, Tworek et al. (2020) found workforce diversity as a critical catalyst 
in improving organizational performance. Again, diversity at the workplace has been found to improve organizational creativity as it provides diverse perspectives to organizational problem identification and definition and equally provides different alternatives in solving organizational problems (Annabi \& Lebovitz, 2018).

Notwithstanding this positive effect associated with workforce diversity, others have found diversity to result in negative organizational effectiveness, with some affecting organizational cohesiveness and cooperation. For example, Dahanayake et al. (2018) observed that workplace diversity could generate conflict amongst employees due to the differences in perception, ideas, behaviors, interests, attitudes, religious differences, political views, and unjustified distribution of resources. The consequence of workplace conflict tends to be quite devastating as unresolved conflict amongst co-workers can decrease team spirit, reduce innovation, affect product quality and consequently lead to poor employee performance and poor organizational outcomes (Aljawarneh \& Atan, 2018; Kyei-Frimpong et al., 2020; Nwadike, 2019).

Nevertheless, it is not every conflict that results in hatred. For instance, when conflicts are appropriately managed, it becomes an essential source of idea building and creativity (Smith, 2020). However, when management chooses to attach less importance to its occurrence at the workplace, it can degenerate into a personal and emotional rift which in effect may disrupt the morale of the employees, organizational culture and even jeopardize organizational performance (Gest, 2016; Zýka \& Drahotský, 2019). In view of the above, we also hypothesize that:

\section{H1: Employee diversity has a positive relationship with competency-based performance.}

\section{Employee commitment and Employee Satisfaction as mediators}

Organizational commitment implies an individual's psychological, emotional, and willingness to remain in an organization (Hung et al., 2018). It is also described as an unrestricted or willing action which is not formally part of the reward arrangement of an organization (Vuong et al., 2020). However, according to Ammari et al. (2017), this expression of willingness by individuals in organizations are related to goals, values equivalence, organizational culture, investments in the development of employees, and the zeal to stay in organizations. Moreover, sustaining organizational commitment and satisfaction amongst employees, especially a diverse group, is increasingly a challenge for organizations (Wagner \& Hollenbeck, 2020). Notwithstanding, minority employees such as women and workers of color have their satisfaction and commitment levels hampered due to perceived discrimination (Buttner \& Lowe, 2017). Therefore, for managers to improve employee cohesion, steps must be taken to provide equal platforms and opportunities among diverse employees (Cletus et al., 2018). Therefore, we propose that;

H2a: Employee commitment positively mediates employee diversity and competency-based performance.

Amongst the vital components of the organizational-employee relationship is employee job satisfaction and employee commitment (Djastuti, 2019). According to Liu et al. (2016), job satisfaction can be defined as a pleasurable or positive emotional state resulting from one's appraisal of a job or experience (Huang, 2019). Extensive literature review abounds on job 
satisfaction suggesting sufficient research on this phenomenon. However, there is relatively little research on employee job satisfaction and employee commitment as mediators between employee diversity and job performance (Alkhateri et al., 2018). Perhaps due to the depth of research concerning employee job satisfaction and employee commitment as a mediator, there is a lack of consensus on the impact of these variables within the organizational setup (Gaudet \& Tremblay, 2017). Therefore, we propose the following hypothesis:

H2b: Employee satisfaction positively mediates employee diversity and competency-based performance.

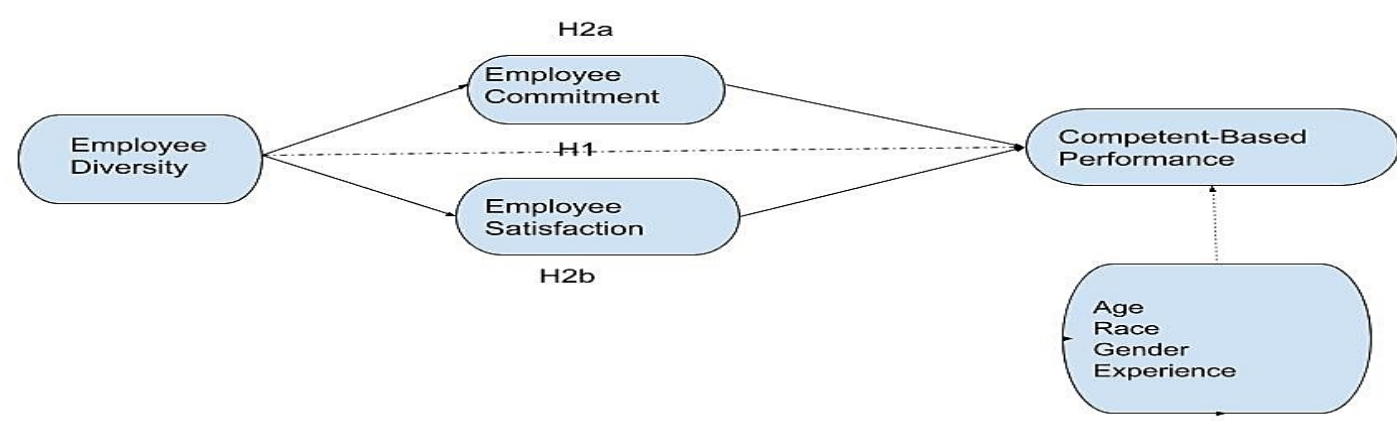

Figure 1. Research model

Source: from the Authors.

\section{Methodology}

\section{Data setting and collection}

A questionnaire was developed, and a stratified random sampling technique was adopted to collect data from the Tomas Bata University in Zlin, the study site. Stratified random sampling is a method of sampling that involves the division of a population into smaller sub-groups known as strata (Smith et al., 2017). In stratified random sampling or stratification, the strata are formed based on members' shared attributes or characteristics such as income or educational attainment, etc. (Song et al., 2016). In this study, the target population was made up of three strata: Academics (professors, Senior Lecturers, Lecturers and Assistant Lecturers (514); postgraduate students (150), and administrative staff (351) within the institution. The questionnaires were distributed in proportion to the number of people in each stratum. Subsequently, concerning data collection and analysis techniques, structured self-administered questionnaires design and online survey distribution were adopted to achieve the overall goal of this study. We distributed 260 questionnaires to the employees and researchers of the institution. As an online survey, we invited the respondents through their emails, as every worker or postgraduate student of the institution had an email address. We also did a follow-up by sending reminders through the email. We received 237 valid responses, representing $91 \%$ of the response rate. The high response rate was made possible because the researchers works in the same University where data was drawn. The analysis of these employees and postgraduate students form part of the various strata, suffice to say that the postgraduate students are considered as employees because they earn a scholarship and as part of their study plan and requirement, they take part in pedagogical activities. Table 1 below depicts the demographic characteristics and profile of the study. 
Table 1. Demographic characteristics of respondents

\begin{tabular}{llll}
\hline & Details of respondents & Frequency & Percent (\%) \\
\hline \multirow{2}{*}{ Gender } & Male & 121 & 51.1 \\
& Female & 116 & 48.9 \\
& $18-25$ & 51 & 21.6 \\
Age & $26-30$ & 81 & 34.2 \\
& $31-35$ & 66 & 27.8 \\
& $36-40$ & 29 & 12.2 \\
& Above 40 & 10 & 4.2 \\
& Diploma & 14 & 5.9 \\
Educational level & Bachelor's Undergraduate & 40 & 16.9 \\
& Master's & 97 & 40.9 \\
& Ph.D. candidates & 66 & 27.9 \\
Status in the organization. & Others & 20 & 8.4 \\
& Academic staff (e.g. Lecturers) & 48 & 20.2 \\
Affective commitment & Postgraduate students /researchers & 80 & 33.6 \\
Normative commitment & Administrative staff & 109 & 46.2 \\
Continuance commitment & & 193 & 81.6 \\
Extreme commitment & & 187 & 78.8 \\
Co-worker Satisfaction & & 174 & 73.3 \\
Supervisory Satisfaction & & 146 & 61.4 \\
Recognition Satisfaction & & 158 & 68.8 \\
Communication Satisfaction & & 133 & 56.1 \\
\hline
\end{tabular}

Sources: Authors' field study (November-December, 2020).

\section{Measures}

All the measures used in this are displayed in figure 1. Employee diversity and from now on (ED) as an independent variable and competency-based performance and from now on (CBP) as a dependent variable. Employee commitment and hereinafter (EC) and satisfaction and from now on (ES) as the mediators. We adopted constructs from the current study. The measures for CBP were adopted from the works of Demo et al. (2012) and ED measures taken from the works of Tuan (2020) with the measure of EC and ES taken from the works (Liu et al., 2016; Meyer et al., 1993). All measurement items were assessed on a five-point Likert scale with (1) being completely disagree and (5) completely agree.

\section{Results}

\section{Measurement model assessment}

The preliminary stage in performing any PLS-SEM is the assessment of measurement models. This is to confirm that the indicator variables are measuring the constructs they are to measure. Therefore, following the suggestions of Hair et al. (2017) and (Khan et al., 2019), the measurement model was assessed by both convergent validity and reliability testing. Consistent with previous investigations, and in acknowledging the steps in using PLS-SEM as previously suggested, the measurement model must be first assessed using the indicator loadings (Hair et al., 2017). Because of this, minimum loadings of approximately 0.561 are considered suitable since they best explain more than 50 percent of the indicator variance, hence providing a satisfactory threshold for item reliability (Shmueli et al., 2019). With this rule of thumb, all items in connection with the reliability indicator showed more than 
50 percent of the indicator loadings, which suggest the level of connections (item correlation) to their respective constructs (see table 2).

Table 2. Factor/outer loadings

\begin{tabular}{lllll}
\hline Indicators & $\begin{array}{c}\text { Competency-based } \\
\text { performance (CBP) }\end{array}$ & $\begin{array}{c}\text { Employee } \\
\text { commitment (EC) }\end{array}$ & $\begin{array}{c}\text { Employee } \\
\text { diversity (ED) }\end{array}$ & $\begin{array}{c}\text { Employee } \\
\text { satisfaction (ES) }\end{array}$ \\
\hline EC1 & & 0.788 & & \\
EC2 & 0.733 & & \\
EC3 & 0.816 & & \\
EC4 & & 0.614 & 0.855 & \\
ED1 & & 0.739 & \\
ED2 & & 0.898 & \\
ED3 & & & & \\
CBP1 & 0.777 & & & \\
CBP2 & 0.815 & & & 0.668 \\
CBP3 & 0.784 & & & 0.561 \\
CBP4 & 0.650 & & & 0.853 \\
ES1 & & & & \\
ES2 & & & \\
ES3 & & & \\
ES4 & & & \\
\end{tabular}

Source: Authors' processing from SmartPLS 3.2.9.

Cronbach alpha (CA) and composite reliability (CR) were used as a metric in the assessment of the internal consistency and reliability of the study measures. As was the case in the work of extant literature (Anderson \& Gerbing, 1988; Shmueli et al., 2019) for CA of 0.5 and (Bagozzi \& Yi, 1988; Sarstedt et al., 2020) for CR of 0.6, which were respectively used as the minimum threshold and rule of thumb. In this study, CA for all construct ranges between 0.731 and 0.785 , whereas CR values were between 0.824 and 0.872 .

The average variance extracted (AVE) was used to measure the extent to which the constructs congregate to explain the variance of all items on each construct for the convergent validity (Fogarty et al., 2014). The minimum acceptable AVE is 0.50, which indicates 50 percent or more of the variance items make up with the specified items. Based on this threshold, all AVE values were above the minimum threshold. Table 3 depicts the values for CA, CR, AVE, rho_A recorded for all constructs.

Table 3. Construct reliability and validity

\begin{tabular}{lcccc}
\hline \multicolumn{1}{c}{ Construct } & $\begin{array}{c}\text { Cronbach } \\
\text { Alpha }\end{array}$ & rho_A & Composite reliability & \multirow{2}{*}{ AVE } \\
\hline Competence-based performance & 0.757 & 0.779 & 0.844 & 0.577 \\
Employee commitment & 0.728 & 0.750 & 0.829 & 0.550 \\
Employee diversity & 0.785 & 0.859 & 0.872 & 0.695 \\
Employee satisfaction & 0.731 & 0.754 & 0.824 & 0.500 \\
\hline
\end{tabular}

NB: AVE-Average Variance Extracted.

Source: Author's processing from SmartPLS 3.2.9.

Aside from testing for convergent validity using AVE, we also examined convergent validity through the Fornell-Lacker criterion (Fornell \& Lacker, 1981). Fornell and Lacker (1981) propose that the estimate of the square root average variance extracted (AVE) should be more significant than the correlation shared between every other construct (see table 4). 
Readers may take a quick look at the inter-construct correlation matrix and the discriminant validity to observe the bolded slanting figures indicating the level of correlation coefficient amongst the observed constructs. The discriminant is established when a construct has a higher value of loaded coefficient beyond other observed variables in a single row or column, as indicated in table 4 . The results shown in Table 4 confirm that the Fornell-Lacker criterion has been met.

Table 4. Test of discriminant validity - Fornell-Larcker Criterion

\begin{tabular}{|c|c|c|c|c|}
\hline Construct & 1 & 2 & 3 & 4 \\
\hline 1=Competency-based performance & 0.759 & & & \\
\hline 2=Employee commitment & 0.646 & 0.742 & & \\
\hline 3=Employee diversity & 0.428 & 0.458 & 0.834 & \\
\hline 4=Employee satisfaction & 0.561 & 0.452 & 0.735 & 0.699 \\
\hline
\end{tabular}

NB: the values in bold (in diagonal) are the squared average variance extracted.

Source: Authors' processing from SmartPLS 3.2.9.

\section{Structural Model- Direct \& mediation analysis}

Beyond the assessment of the measurement model, there is also the need to assess the structural model. The structural results are presented in Table 5. The results show that only one of the five hypotheses was rejected. Specifically, hypothesis (H1), which predicted a positive relationship between employee diversity and competency-based performance, was not confirmed $(\beta=-0.104, t=0.933, p>0.05)$. With the mediated observation it can be observed from table 4 that ED> EC and ES towards (CBP) are all supported (H2a and $\mathrm{H} 2 \mathrm{~b}$ ) with the below statistics; $E D->E C->C B P=\left(\beta=0.510, t^{*} 6.992, p<0.001\right)$ and $E D->E S->C B P=(\beta=0.407$, $\left.\mathrm{t}^{*}=4.311, \mathrm{p}<0.001\right)$, as seen from Table 5 below.

Table 5. Structural model - path coefficient

\begin{tabular}{lllllll}
\hline \multicolumn{1}{c}{ Relationship } & Beta $(\boldsymbol{\beta})$ & $\begin{array}{l}\text { Mean } \\
\text { value }\end{array}$ & SD error & t-value & P-Values & $\begin{array}{c}\text { Empirical } \\
\text { Remarks }\end{array}$ \\
\hline H2a:EC->CBP & 0.510 & 0.516 & 0.073 & 6.992 & 0.000 & Supported \\
H1: ED->CBP & -0.104 & -0.116 & 0.111 & 0.933 & 0.351 & Not supported \\
ED -> EC & 0.458 & 0.467 & 0.089 & 5.140 & 0.000 & Supported \\
ED-> ES & 0.735 & 0.741 & 0.059 & 12.426 & 0.000 & Supported \\
H2b:ES->CBP & 0.407 & 0.415 & 0.094 & 4.311 & 0.000 & Supported \\
\hline
\end{tabular}

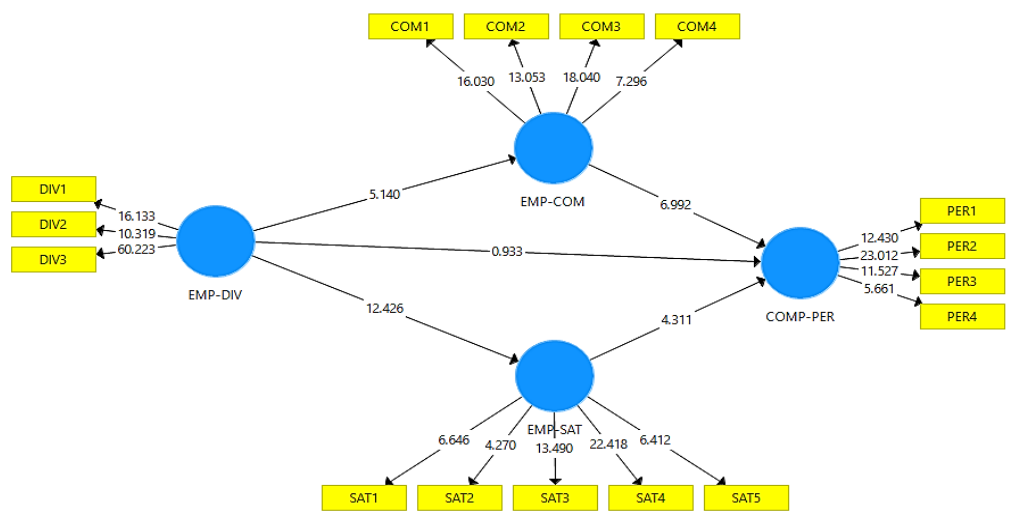

Figure 2. Estimated model from SmartPLS. 3.2.9

Source: Authors' processing from SmartPLS 3.2.9. 


\section{Discussion and theoretical and practical Importance}

The main objective of this study was to examine the mediating role of commitment and job satisfaction in the relationship between employee diversity and competency-based performance. Firstly, we found that the relationship between employee diversity and competency-based performance was not significant, a finding which adds to the mixedresults reported in diversity and performance studies. Indeed, as indicated in the literature review section, previous empirical studies on the link between diversity and performance produced mixed results (Gomez \& Bernet, 2019). Researchers believe that the actual effect of diversity on employee performance is more complicated than envisaged (Gomez \& Bernet, 2019; Tekleab et al., 2016). Therefore, there is the need for a more varied investigation into employee diversity and performance on account of complexities in modern organizational trends.

Although our study looked at the link between diversity and performance, the mediating role of employee commitment and employee satisfaction is also examined. We found that although the relationship between diversity and competency-based performance is not significant, the relationship is strengthened when commitment and job satisfaction mediate it. The results of our study add to recent investigations about the importance of diversity in influencing employee performance (Archer \& Francis, 2019; Hajro et al., 2017; Zahra et al., 2020). As a result, the main point of this study is the primary diversity considerations, thus; age, gender, race, and experience. The results corroborate with the assertion made by Archer and Francis (2019) that some of these diversity considerations have been well researched more than others. However, the evidence of individual aspects differs. There are few exceptions due to the operationalization of these various features and their methodology (Trepte \& Loy, 2017). Globalization also demands more interrelation amongst people from different backgrounds (Harris, 2019), which is in tandem with the outcome of this study; however, amongst the primary diversity features examined relative to this study at the Tomas Bata University in Zlin, Czech Republic, race compared to experience, age and gender seems to be relatively minimal due to the dominance of the indigenes. Age, experience, and gender are on a balance since there is a more or less equal number of these features in the institution.

In addition, People no longer live in isolation irrespective of their age, gender, race, and experience. Therefore, Hajro et al. (2017) argue that non-profit and profit organizations need diversity to be more creative, innovative, and more susceptible to change in this contemporary times. The gradual entry of Africans, Asians, and other racial groups has complemented the age, experience, and gender within the organizational setup of Tomas Bata University. Hence, improving diversity has not only become necessary in the understudied context but has equally become a vital tool in modern-day management (Hajro et al., 2017). For instance, Tekleab et al. (2016) posit that the increasing rate of diversity in the corporate world requires institutional heads to recognize this new evolution and make the necessary managerial changes to suit this emerging trend. The finding also suggests that the actual effect of diversity may vary due to forms of diversity which is consistent with previous studies (Cunningham, 2019; Guest, 2017). Social categorization and social identity theories give credence to the main effect of racial diversity; greater diversity is linked with less social integration, more conflict, and less unity in groups, which is inimical to organizational performance (Trepte \& Loy, 2017). In contrast, the extreme level of diversity in terms of race decreases organizational performance, while a high level of gender diversity 
increases organizational performance. (Cunningham, 2019; Ferreira et al., 2020; Guillaume et al., 2017)

Some researchers believe that employee commitment affects organizational effectiveness through the improvement of both social and psychological contracts, which consequently supports task performance (Ahmad et al., 2019; Vuong et al., 2020). Since organizations cannot predict or anticipate the behaviour of their employees, it becomes essential to have employees that have a strong emotional attachment towards an organization since that may influence their attitude and behaviour at the workplace (Habib et al., 2019; Themba et al., 2019). Accordingly, the antecedent and predictors of commitment due to its effect on employee behaviour must focus on managers and researchers (A. Ahmad, 2018). The results derived from the data analysis of the data collected from the employees supported the hypothesis ( $\mathrm{H} 2 \mathrm{a}$ ), which confirms a significant mediating role of commitment between diversity and competency-based performance. This is supported by the assertions of (Solinger et al., 2016; Villanueva-Flores et al., 2017; Villesèche et al., 2018). These authors argue that employee attachment towards an organization may improve their acceptance of the organizational policy. Diversity in terms of age, race, gender, and experience are all factors that improve organizational outcomes (De Roeck \& Maon, 2018). However, there must be some catalysts too that support diversity (Lavieri \& Bhat, 2019). For instance, an organization's diversity policy may be thwarted without such a catalyst, particularly when employees begin to doubt workers' abilities from different tribes or regions. Accordingly, employees' commitment to their organization could catalyse and support workplace diversity.

In this study, $78.8 \%$ of the respondents indicated that they feel emotionally attached to the institution, while $81.6 \%$ insisted that they remain loyal to the organization. Again, $73.3 \%$ believe that they have limited choice to consider leaving the institution. Also, a maximum of $61.4 \%$ of the participants was even willing to work for free at this organization. Interestingly, their high level of commitment towards the organization made them highly tolerant of one another, even when a colleague worker came from a different region or had a different identity. This assertion confirms arguments made by researchers like (Keskes 2014; Meyer et al., 1993; Mone et al., 2018), as they argued that employees' high commitment made them very receptive to organization policies even when it goes against their fundamental belief.

When it comes to employee satisfaction, it represents terminology used to describe whether employees are happy and fulfilling their desires and needs at the workplace (Bratton \& Gold, 2017). Employee motivation, employee goal achievement, and positive employee morale in the workplace indicate how satisfied an employee is towards an organization (Badubi, 2017). One of the primary roles for organizations to achieve their objectives is by ensuring the complete satisfaction of their workforce. Satisfied employees will reciprocate this positive feeling by showing love and care towards the organization's customers (Kloutsiniotis \& Mihail, 2018). Addis et al. (2018) argue that better pay, good training programs, and interest in the security of employees are an indication of proper organizational care of their employees, hence leading to their satisfaction.

Moreover, employees willing to work together can work beyond expectations, raise their capacity to match their manager's expectations, and even work more efficiently and effectively towards organizational goals (Clarkson, 2016). The satisfaction of employees and clients has become a focal point for researchers since it has a key influence on organizational 
bottom-line (Huang, 2019; Huang \& Su, 2016). Data analysis of the employees of the sampled population corroborated the assertions of various researchers (Alkhateri et al., 2018; Djastuti 2019; Liu et al., 2016). Thus, $66.8 \%$ of respondents say they enjoyed cooperation from their co-workers, $56.1 \%$ also held that they enjoy instructions from their supervisors, $75.3 \%$ are satisfied with the recognition from their institution, and finally, 84.9\% agree that they receive first-hand information from the institution. The concept of satisfaction elaborates on how content or fulfilled an employee is for their desire and needs at work. Employee satisfaction encompasses primary concerns and needs. Again, employee satisfaction is of the utmost importance in any organization irrespective of its size, and it is equally essential for the employee just as it is for the organization. In addition, some of the fundamental importance of satisfaction to an organization includes protection from employee absenteeism, increase in productivity, and better relationships between employees and their clients, resulting in improved customer service experience. For an employee, the importance of satisfaction includes having the belief that the initial satisfaction will persist for a long run, an employee will have the peace of mind to concentrate on their job, the employee will feel a sense of responsibility and belongingness in their organization, and finally, an employee may be able to put much effort to gain recognition from the organization. Therefore, we suggest that managers pay attention to their employees' needs at their various institutions to improve their satisfaction. A satisfied employee will be committed to an organization, which will have a positive effect on their performance and the organization's performance as a whole.

\section{Conclusion, limitations, and future research Conclusion}

In conclusion, the study's main aim was to explore the mediating role of employee commitment and employee satisfaction in the relationship between workplace diversity and competency-based performance. To assess this mediating effect, we tested the linear relationship between diversity and competency-based performance. Contrary to our prediction, diversity was found to have an insignificant relationship with competency-based performance. However, we find that both commitment and job satisfaction play a significant mediating role in the relationship between diversity and competency-based performance. These findings, indeed, have several implications for theory and practice.

\section{Theoretical and managerial implications of the study}

Our findings provide evidence to the current debate that workplace diversity and performance nexus are inconclusive and equivocal. Specifically, our finding that diversity does not significantly correlate with performance strengthens the mixed-results evidence on diversity and performance studies. The implication is that there is a need for further research in diversity and organizational performance. Moreover, our study also extends the literature on possible ways to make diversity positively influence organizational performance. We add to the literature because our study findings have indicated that for diversity to influence organizational performance positively, commitment and job satisfaction could play a major.

The study also has several managerial implications. Firstly, our findings inform managers that diversity pursuit does not always translate to organizational performance. This means that our findings imply that managers should be aware of the negative consequence of diversity. Secondly, by our findings, managers are provided with evidence that employee commitment is vital in the diversity and performance relationship. This 
implies that while managers try to make their workplace more diverse and inclusive, they should also make sure that employees are committed to their organizations. This means they should engage strategies such as career growth opportunities, good employee-employer relationships, respect for employee needs, and others to foster employee commitment. Thirdly, we also articulate that job satisfaction is seminal in the diversity and performance strategy through our findings. This finding encourages managers to ensure employees are satisfied with their jobs. This could be achieved through the introduction of a good reward and pay system, job security, and working conditions.

\section{Limitations and future research}

While our study has several implications for theory and practice, the study setting may limit the generalizability of its findings. Firstly, we acknowledge a limitation that since diversity and performance studies are complex, taking a sample from only one educational institution may turn the applicability of findings to the European community into a challenge. Additionally, the sample was taken from only a public university in the Czech Republic. Future research should consider samples from private universities and other organisations. Our study finding is also limited in that our measures were only self-reported, which could be interpreted differently or mean differently to the respondents. In this regard, future research could use objective performance measures rather than self-report.

Further, the study concentrated on only primary diversity considerations rather than secondary diversity considerations. Hence, consideration of secondary diversity could have given a much broader perspective on workplace diversity. Based on the unit of analysis, this can be described as a pilot study due to the probability of getting different variations from different categories of the same participants. We recommend that future research in diversity must be directed at the secondary diversity considerations to give a broader perspective. Despite these limitations of this research being a pilot study still adds to our understanding of the mediating role employee commitment and job satisfaction have on the relationship between employee diversity and competency-based performance. With the world gradually becoming a global village, diversity must be explored at various geographical locations to give impetus to the true meaning of diversity and its relevance in employee performance from a global perspective.

\section{Acknowledgment}

This study was supported by Tomas Bata University in Zlin, through; IGA/FaME/2020/003. Training and development programs and the consequence on employee's commitment, satisfaction and organizational performance: analysis from Czech, public service sector.

The study was supported with funding from the Internal Grant Agency of the Faculty of Management and Economics at Tomas Bata University in Zlin, Czech Republic, Research Project No. IGA/FaME/2021/003 entitled "Consumer behaviour and Performance management of firms in a competitive digital world."

\section{References}

Addis, S., Dvivedi, A., \& Beshah, B. (2018). Determinants of job satisfaction in Ethiopia: evidence from the leather industry. African Journal of Economic and Management Studies. 
Ahmad, A. (2018). The relationship among job characteristics organizational commitment and employee turnover intentions: A reciprocation perspective. Journal of WorkApplied Management.

Ahmad, I., Donia, M. B., Khan, A., \& Waris, M. (2019). Do as I say and do as I do? The mediating role of psychological contract fulfillment in the relationship between ethical leadership and employee extra-role performance. Personnel review.

Al-Abdullat, B. M., \& Dababneh, A. (2018). The mediating effect of job satisfaction on the relationship between organizational culture and knowledge management in Jordanian banking sector. Benchmarking: An International Journal.

Alba, R., \& Duyvendak, J. W. (2019). What about the mainstream? Assimilation in superdiverse times. Ethnic and racial studies, 42(1), 105-124.

Alford, J., \& Greve, C. (2017). Strategy in the public and private sectors: Similarities, differences and changes. Administrative Sciences, 7(4), 35.

Aljawarneh, N. M. S., \& Atan, T. (2018). Linking tolerance to workplace incivility, service innovative, knowledge hiding, and job search behavior: The mediating role of employee cynicism. Negotiation and Conflict Management Research, 11(4), 298-320.

Alkhateri, A. S., Abuelhassan, A. E., Khalifa, G. S., Nusari, M., \& Ameen, A. (2018). The Impact of perceived supervisor support on employee's turnover intention: The Mediating role of job satisfaction and affective organizational commitment. International Business Management, 12(7), 477-492.

Ammari, G., Alkurdi, B., Alshurideh, A., \& Alrowwad, A. (2017). Investigating the Impact of communication satisfaction on organizational commitment: a practical approach to increase employees' loyalty. International Journal of Marketing Studies, 9(2), 113-133.

Anderson, J. C., \& Gerbing, D. W. (1988). Structural equation modeling in practice: A review and recommended two-step approach. Psychological bulletin, 103(3), 411.

Annabi, H., \& Lebovitz, S. (2018). Improving the retention of women in the IT workforce: An investigation of gender diversity interventions in the USA. Information Systems Journal, 28(6), 1049-1081.

Archer, L., \& Francis, B. (2006). Understanding minority ethnic achievement: Race, gender, class and'success'. Routledge.

Avery, D. R., McKay, P. F., \& Wilson, D. C. (2008). What are the odds? How demographic similarity affects the prevalence of perceived employment discrimination. Journal of Applied Psychology, 93(2), 235.

Badubi, R. M. (2017). Theories of motivation and their application in organizations: A risk analysis. International Journal of Innovation and Economic Development, 3(3), 44-51.

Bagozzi, R. P., \& Yi, Y. (1988). On the evaluation of structural equation models. Journal of the academy of marketing science, 16(1), 74-94.

Benjamin, D. J., Berger, J. O., Johannesson, M., Nosek, B. A., Wagenmakers, E. J., Berk, R., ... \& Johnson, V. E. (2018). Redefine statistical significance. Nature human behaviour, 2(1), 6-10.

Bileviciute, E., Draksas, R., Nevera, A., \& Vainiute, M. (2019). Competitiveness in higher education: the case of university management. Journal of competitiveness, 11(4), 5.

Bratton, J., \& Gold, J. (2017). Human resource management: theory and practice. Palgrave.

Buttner, E. H., \& Lowe, K. B. (2017). The relationship between perceived pay equity, productivity, and organizational commitment for US professionals of color. Equality, Diversity and Inclusion: An International Journal. 
Choi, Y., \& Dickson, D. R. (2009). A case study into the benefits of management training programs: Impacts on hotel employee turnover and satisfaction level. Journal of Human Resources in Hospitality \& Tourism, 9(1), 103-116.

Clarkson, M. B. (2016). A stakeholder framework for analysing and evaluating corporate social performance (pp. 243-274). University of Toronto Press.

Cletus, H. E., Mahmood, N. A., Umar, A., \& Ibrahim, A. D. (2018). Prospects and challenges of workplace diversity in modern day organizations: A critical review. HOLISTICAJournal of Business and Public Administration, 9(2), 35-52.

Cunningham, G. B. (2019). Diversity and inclusion in sport organizations: A multilevel perspective. Routledge.

De Roeck, K., \& Maon, F. (2018). Building the theoretical puzzle of employees' reactions to corporate social responsibility: An integrative conceptual framework and research agenda. Journal of Business Ethics, 149(3), 609-625.

Demo, G., Neiva, E. R., Nunes, I., \& Rozzett, K. (2012). Human resources management policies and practices scale (HRMPPS): Exploratory and confirmatory factor analysis. BARBrazilian Administration Review, 9, 395-420.

Djastuti, I. (2019). Turnitin: Fun at Work and Employee Performance: The Roles of Job Satisfaction and Organizational Commitment in Manufacturing Companies.

Ferreira, J., Coelho, A., \& Moutinho, L. (2020). Dynamic capabilities, creativity and innovation capability and their Impact on competitive advantage and firm performance: The moderating role of entrepreneurial orientation. Technovation, 92, 102061.

Fogarty, L., Kim, Y. M., Juon, H. S., Tappis, H., Noh, J. W., Zainullah, P., \& Rozario, A. (2014). Job satisfaction and retention of health-care providers in Afghanistan and Malawi. Human resources for health, 12(1), 1-12.

Forés, B., \& Camisón, C. (2016). Does incremental and radical innovation performance depend on different types of knowledge accumulation capabilities and organizational size? Journal of business research, 69(2), 831-848.

Fornell, C., \& Larcker, D. F. (1981). Structural equation models with unobservable variables and measurement error: Algebra and statistics.

Gaudet, M. C., \& Tremblay, M. (2017). Initiating structure leadership and employee behaviors: the role of perceived organizational support, affective commitment and leadermember exchange. European Management Journal, 35(5), 663-675.

Gest, J. (2016). The new minority: White working-class politics in an age of immigration and inequality. Oxford University Press.

Goldberg, C. B., Riordan, C., \& Schaffer, B. S. (2010). Does social identity theory underlie relational demography? A test of the moderating effects of uncertainty reduction and status enhancement on similarity effects. Human Relations, 63(7), 903-926.

Gomez, L. E., \& Bernet, P. (2019). Diversity improves performance and outcomes. Journal of the National Medical Association, 111(4), 383-392.

Guest, D. E. (2017). Human resource management and employee well-being: Towards a new analytic framework. Human Resource Management Journal, 27(1), 22-38.

Guillaume, Y. R., Dawson, J. F., Otaye-Ebede, L., Woods, S. A., \& West, M. A. (2017). Harnessing demographic differences in organizations: What moderates the effects of workplace diversity? Journal of Organizational Behavior, 38(2), 276-303.

Habib, M., Abbas, J., \& Noman, R. (2019). Is human capital, intellectual property rights, and research and development expenditures really important for total factor 
productivity? An empirical analysis. International Journal of Social Economics.

Hair Jr, J. F., Matthews, L. M., Matthews, R. L., \& Sarstedt, M. (2017). PLS-SEM or CB-SEM: updated guidelines on which method to use. International Journal of Multivariate Data Analysis, 1(2), 107-123.

Hair Jr, J. F., Sarstedt, M., Ringle, C. M., \& Gudergan, S. P. (2017). Advanced issues in partial least squares structural equation modeling. saGe publications.

Hajro, A., Gibson, C. B., \& Pudelko, M. (2017). Knowledge exchange processes in multicultural teams: Linking organizational diversity climates to teams' effectiveness. Academy of Management Journal, 60(1), 345-372.

Hakim, C. (2019). Key issues in women's work: Female diversity and the polarisation of women's employment. Routledge-Cavendish.

Harris, A. (2019). Young people and everyday multiculturalism. Routledge.

Huang, W. R. (2019). Job training satisfaction, job satisfaction, and job performance. Career Development and Job Satisfaction.

Huang, W. R., \& Su, C. H. (2016). The mediating role of job satisfaction in the relationship between job training satisfaction and turnover intentions. Industrial and Commercial Training.

Hung, L. M., Lee, Y. S., \& Lee, D. C. (2018). The moderating effects of salary satisfaction and working pressure on the organizational climate, organizational commitment to turnover intention. International Journal of Business \& Society, 19(1).

Kadiresan, V., Selamat, M. H., Selladurai, S., Ramendran, C. S., \& Mohamed, R. K. M. H. (2015). Performance appraisal and training and development of human resource management practices (HRM) on organizational commitment and turnover intention. Asian Social Science, 11(24), 162.

Keskes, I. (2014). Relationship between leadership styles and dimensions of employee organizational commitment: A critical review and discussion of future directions. Intangible Capital, 10(1), 26-51.

Khan, G. F., Sarstedt, M., Shiau, W. L., Hair, J. F., Ringle, C. M., \& Fritze, M. P. (2019). Methodological research on partial least squares structural equation modeling (PLSSEM): an analysis based on social network approaches. Internet Research.

King, E., Hebl, M., \& Beal, D. (2009). Conflict and cooperation in diverse workgroups. Journal of Social Issues, 65(2), 261.

King, R. (2019). Diverse, fragile and fragmented: The new map of European Migration. Central and Eastern European Migration Review, 8(1), 9-32.

Kittay, E. F. (2019). Love's labor: Essays on women, equality and dependency. Routledge.

Kloutsiniotis, P. V., \& Mihail, D. M. (2018). The link between perceived high-performance work practices, employee attitudes and service quality: The mediating and moderating role of trust. Employee Relations.

Kools, M., \& Stoll, L. (2016). What makes a school a learning organisation?

Kyei-Frimpong, D., Asomaning, A. K., Adwubi, F., \& Oppong, T. (2020). An Assessment of Organisational Conflicts On Work Performance Within Sinapi Aba Savings And Loans Ltd (Doctoral Dissertation).

Lavieri, P. S., \& Bhat, C. R. (2019). Modeling individuals' willingness to share trips with strangers in an autonomous vehicle future. Transportation research part A: policy and practice, $124,242-261$.

Lee, H. K. (2019). The new patron state in South Korea: cultural policy, democracy and the 
market economy. International journal of cultural policy, 25(1), 48-62.

Liu, Y., Aungsuroch, Y., \& Yunibhand, J. (2016). Job satisfaction in nursing: a concept analysis study. International nursing review, 63(1), 84-91.

Meyer, J. P., Allen, N. J., \& Smith, C. A. (1993). Commitment to organizations and occupations: Extension and test of a three-component conceptualization. Journal of applied psychology, 78(4), 538.

Mone, E. M., \& London, M. (2018). Employee engagement through effective performance management: A practical guide for managers. Routledge.

Ness, D., \& Lin, C. L. (2015). International education: An encyclopedia of contemporary issues and systems. Routledge.

Nwadike, R.O. (2019). Conflict management strategy and performance in the nigerian breweries plc in south-east, Nigeria. Ijme, 1(1).

Pinar, M., McCuddy, M. K., Birkan, I., \& Kozak, M. (2011). Gender diversity in the hospitality industry: An empirical study in Turkey. International Journal of Hospitality Management, 30(1), 73-81.

Pitts, D. (2009). Diversity management, job satisfaction, and performance: Evidence from US federal agencies. Public Administration Review, 69(2), 328-338.

Přívara, A., \& Kiner, A. (2020). Immigrant Employment in the Slovak Hospitality Industry: Profiles, Experience, and Education: Přívara, A., Kiner, A. (2020). Immigrant Employment in the Slovak Hospitality Industry: Profiles, Experience, and Education. Journal of Tourism and Services, 20 (11), 167-182. Journal of Tourism and Services, 11(21), 166-182.

Pudjiarti, E. S. (2018). Elements of entrepreneurship in private universities: Organizational change capacity, innovative capability and the performance. Journal of Entrepreneurship Education, 21(2), 1-15.

Roberson, Q. M. (2019). Diversity in the workplace: A review, synthesis, and future research agenda. Annual Review of Organizational Psychology and Organizational Behavior, 6, 69-88.

Sarstedt, M., Ringle, C. M., Cheah, J. H., Ting, H., Moisescu, O. I., \& Radomir, L. (2020). Structural model robustness checks in PLS-SEM. Tourism Economics, 26(4), 531-554.

Shalley, C. E., \& Gilson, L. L. (2017). Creativity and the management of technology: Balancing creativity and standardization. Production and Operations Management, 26(4), 605-616.

Shmueli, G., Sarstedt, M., Hair, J. F., Cheah, J. H., Ting, H., Vaithilingam, S., \& Ringle, C. M. (2019). Predictive model assessment in PLS-SEM: guidelines for using PLSpredict. European Journal of Marketing.

Siyambalapitiya, J., Zhang, X., \& Liu, X. (2018). Green human resource management: A proposed model in the context of Sri Lanka's tourism industry. Journal of Cleaner Production, 201, 542-555.

Smith, A. N., Anderson, M. J., \& Pawley, M. D. (2017). Could ecologists be more random? Straightforward alternatives to haphazard spatial sampling. Ecography, 40(11), 1251-1255.

Smith, D. G. (2020). Diversity's promise for higher education: Making it work. JHU Press.

Solinger, O. N., Hofmans, J., Bal, P. M., \& Jansen, P. G. (2016). Bouncing back from psychological contract breach: How commitment recovers over time. Journal of Organizational Behavior, 37(4), 494-514. 
Song, J., Cavusgil, E., Li, J., \& Luo, R. (2016). Social stratification and mobility among Chinese middle-class households: An empirical investigation. International Business Review, 25(3), 646-656.

Stojanovic, A., Milosevic, I., Arsic, S., Urosevic, S., \& Mihajlovic, I. (2020). Corporate social responsibility as a determinant of employee loyalty and business performance. Journal of Competitiveness, 12(2), 149.

Sullivan, M. L. (2018). Getting paid. Cornell University Press.

Vuong, B. N., Giao, H. N. K., \& Duy Tung, D. (2020). A model of organizational culture for enhancing organizational commitment in telecom industry: Evidence from Vietnam. WSEAS Transactions on Business and Economics, 17(2020), 215-224.

Tekleab, A. G., Karaca, A., Quigley, N. R., \& Tsang, E. W. (2016). Re-examining the functional diversity - performance relationship: The roles of behavioral integration, team cohesion, and team learning. Journal of Business Research, 69(9), 3500-3507.

Themba, O. S., Razak, N., \& Sjahruddin, H. (2019). Increasing customers' loyalty. The contribution of marketing strategy, service quality and customer satisfaction. Archives of Business Research, 7(2).

Trepte, S., \& Loy, L. S. (2017). Social identity theory and self-categorization theory. The international encyclopedia of media effects, 1-13.

Tuan, L. T. (2020). Can managing employee diversity be a pathway to creativity for tour companies? International journal of contemporary hospitality management.

Tworek, K., Zgrzywa-Ziemak, A., \& Kamiński, R. (2020). Workforce diversity and organizational performance - a study of European football clubs. Argumenta Oeconomica, 45(2), 189-211.

Villanueva-Flores, M., Valle, R., \& Bornay-Barrachina, M. (2017). Perceptions of discrimination and distributive injustice among people with physical disabilities: in jobs, compensation and career development. Personnel Review.

Villesèche, F., Muhr, S. L., \& Holck, L. (2018). Diversity and identity in the workplace: Connections and perspectives. Springer.

Wagner, J. A., \& Hollenbeck, J. R. (2020). Organizational behavior: Securing competitive advantage. Routledge.

Zahra, S. A., Neubaum, D. O., \& Hayton, J. (2020). What do we know about knowledge integration: Fusing micro-and macro-organizational perspectives. Academy of Management Annals, 14(1), 160-194.

Zopiatis, A., Constanti, P., Theocharous, A.L., 2014. Job involvement, commitment, satisfaction and turnover: Evidence from hotel employees in Cyprus. Tour. Manag. 41, 129-140.

Zýka, J., \& Drahotský, I. (2019). Methodology for Assessing the Impact of Workplace Ergonomic Factors on Airport Security Screener's Reliability and Performance. Journal of Tourism and Services, volume 10, issue: 18. 